\title{
Parry-Romberg-szindróma
}

\author{
Tamás Tímea dr. ${ }^{1}$ - Iszlai Zoltán dr. ${ }^{1}$ \\ Szücs Gabriella dr. ${ }^{2}$ - Karosi Tamás dr. ${ }^{1}$ \\ ${ }^{1}$ Borsod-Abaúj-Zemplén Megyei Központi Kórház és Egyetemi Oktatókórház, \\ Fül-Orr-Gégészeti és Fej-Nyaksebészeti Osztály, Miskolc \\ ${ }^{2}$ Debreceni Egyetem, Klinikai Központ, Belgyógyászati Klinika, Reumatológia Tanszék, Debrecen
}

\begin{abstract}
A Parry-Romberg-szindróma ritka, lassan progrediáló, autolimitált betegség, melyet unilateralis arcfélatrophia jellemez. Általában gyerek-, fiatal felnőtt korban manifesztálódik. Az atrophia mértékének, illetve a társuló egyéb tünetek változatosságának következtében a betegség diagnózisa, a prognózis megítélése és a kezelés nagy kihívást jelent. Az esetbemutatás célja rávilágítani a diagnózis felállításának nehézségeire, bemutatni a beteg kivizsgálásának lépéseit, felhívni a figyelmet a mútét megfelelő időzítésének fontosságára, a hemifacialis atrophia mértékének megfelelő mútét kiválasztására, illetve a szindrómával gyakran előforduló betegségek keresésére.

Orv Hetil. 2020; 161(28): 1181-1185.
\end{abstract}

Kulcsszavak: Parry-Romberg-szindróma, scleroderma, Lyme, rekonstrukció

\section{Parry-Romberg syndrome}

Parry-Romberg syndrome is a rare, slowly progressive, autolimitated disease, characterized by unilateral facial atrophy. It is usually manifested in childhood and young adulthood. Because of the degree of atrophy and the variety of symptoms, the diagnosis, prognosis, and treatment of Parry-Romberg syndrome are a major challenge. The purpose of this case presentation is to highlight the difficulty of establishing the diagnosis, furthermore, to present the steps of examining the patient and to draw attention to the importance of proper timing of the surgery. Moreover, it wants to emphasize the importance of looking for diseases that often occur with the mentioned syndrome.

Keywords: Parry-Romberg syndrome, scleroderma, Lyme, reconstruction

Tamás T, Iszlai Z, Szű́cs G, Karosi T. [Parry-Romberg syndrome]. Orv Hetil. 2020; 161(28): 1181-1185.

(Beérkezett: 2020. február 12.; elfogadva: 2020. március 24.)

\section{Rövidítések}

$\mathrm{CT}=$ (computed tomography) számítógépes tomográfia; $\mathrm{EMG}=$ elektromiográfia; $\operatorname{IgG}=$ immunglobulin $-\mathrm{G} ; \mathrm{MR}=$ (magnetic resonance) mágneses rezonancia; PRS = ParryRomberg-szindróma; RF = reumatoid faktor

A 43 éves nóbeteg jobb oldali arcaszimmetria (1. ábra), fejfájás, illetve a jobb szemben kialakult idegentest-érzés miatt érkezett ambulanciánkra. Anamnéziséből kiemelendő, hogy kisgyermekkorban a jobb szemébe oltott mész került, ezt követően látása gyengébb lett, illetve hogy autóbalesetben évekkel ezelőtt agyrázkódást szenvedett; családi anamnézisében pedig a maternél vitiligo jelenléte.

A betegség lefolyása betegünknél a következőképpen alakult: a beteg először 10 éves korában észlelte az állá- nak jobb oldalán kialakuló fehéres behúzódást, mely fokozatosan, lassan progrediált. 16 éves korára a jobb arcfél sorvadása szembetűnővé vált, szájzugelhúzódás jelentkezett; a háton a gerinc mellett kétoldalt 1-1 tenyérnyi területen a bőr behúzódott, barnásan pigmentálttá vált, nyelve a jobb oldalon atrofizált, enophthalmus alakult ki.

A betegnél 2-3 éve fejfájás, a jobb szemben idegentestérzés, az állon viszkető érzés, izomrángások jelentek meg; arcaszimmetriája az utóbbi években nem romlott.

Osztályunkon szövettani mintavétel történt. A szövettani eredmény igazolta a subepithelialis elasztikus rostok változatos eloszlását, részben degeneráció jelenlétével, a dermalis zóna elvékonyodását (2. ábra), illetve mérsékelt perivascularis lymphocytás infiltrációt elszórtan. Koponya-CT-, illetve -MR-vizsgálat készült, melyen int- 


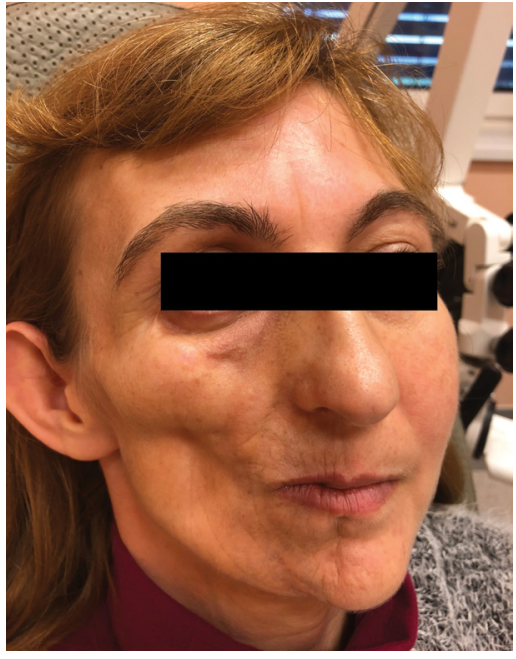

1. ábra $\quad$ Preoperatív kép: jobb oldali hemifacialis atrophia

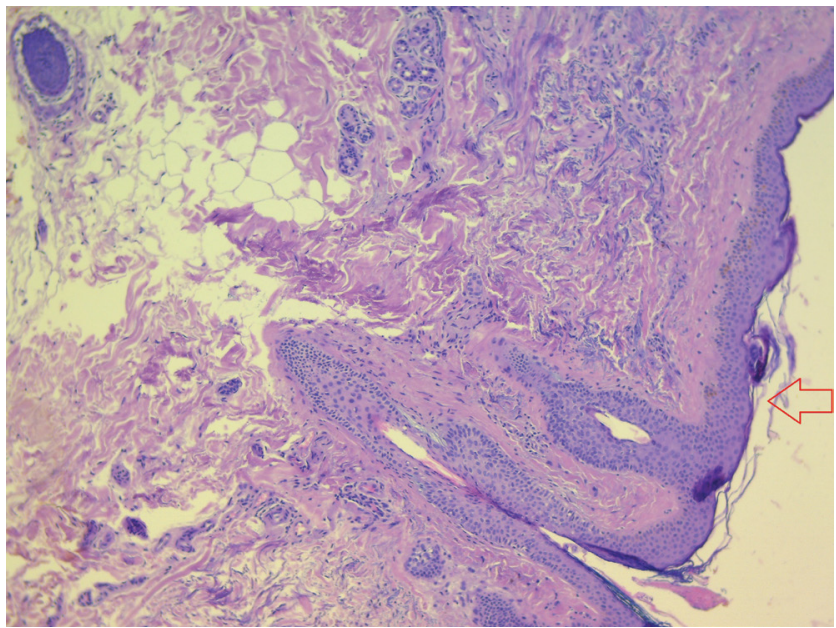

2. ábra

Szövettan: subepithelialis elasztikus rostok változatos eloszlása részben degeneráció jelenlétével, a dermalis zóna elvékonyodásával (piros nyíl)

racranialis eltérés nem volt észlelhető; kimutatta az enophthalmust (3. ábra), a subcutan zsírszövet elkeskenyedését, illetve közepes arcizom-atrophiát (4. ábra). Csontdestrukció nem volt jelen.

Ideggyógyászati vizsgálat történt. Az EMG-vizsgálat izommúködés-zavart nem igazolt.

Kiegészítő laborvizsgálatokat végeztünk, melyek eredményei közül kiemelendő az RF kismértékű emelkedése $(20 \mathrm{UI} / \mathrm{ml})$, illetve a vírusszerológiai vizsgálattal igazolt Lyme-IgG-pozitivitás.

Ezt követően reumatológiai-immunológiai szakvizsgálat, véleményezés történt, mely a betegséget inaktív fázisúnak véleményezte, és lokális kezelést, illetve a jelen stádiumban már elvégezhető plasztikai mütétet javasolt.

Mivel elörehaladott Parry-Romberg-szindrómában (PRS) az immunszuppresszív kezelésre nincs meggyőző adat, a további kezelés szempontjából plasztikai mütét mellett döntöttünk. A beteget előzetesen felvilágosítottuk a zsírszövet részleges atrophiája miatt az esetleges többlépcsős mútéti megoldásról.

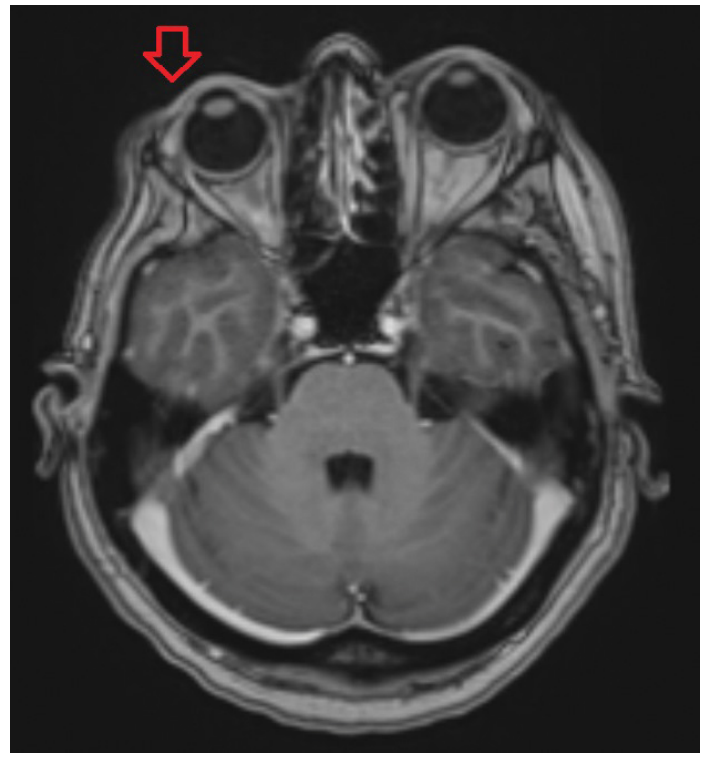

3. ábra
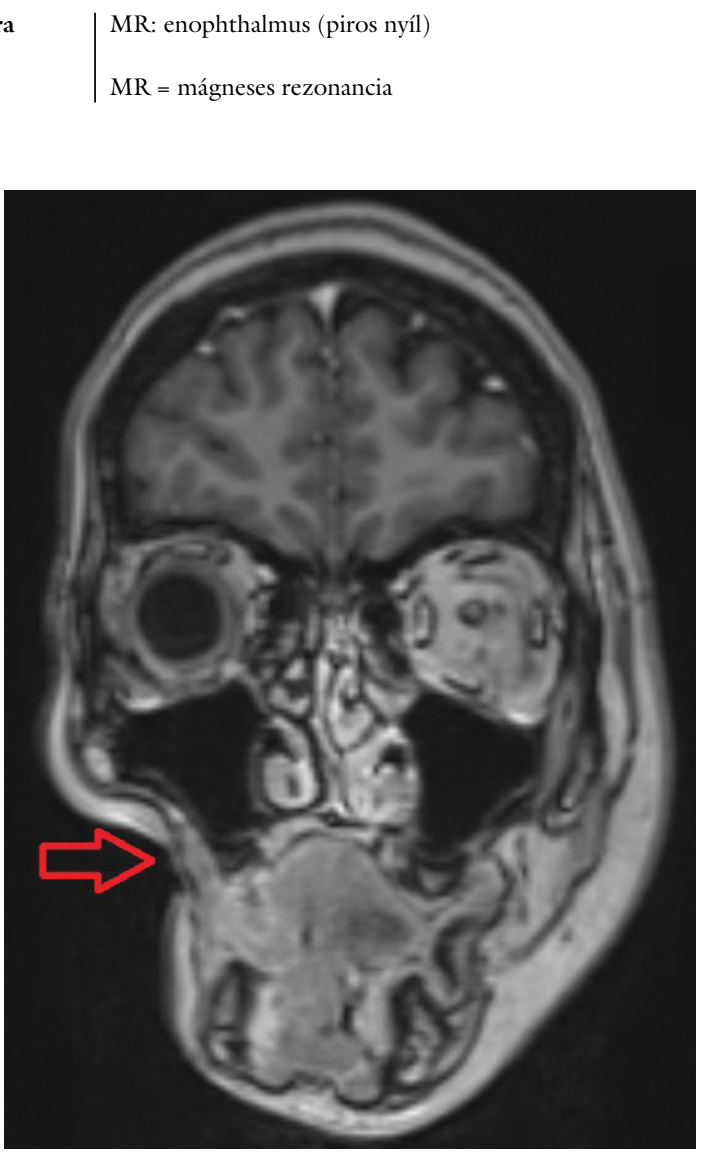

4. ábra

MR: cutis, subcutis, illetve izom elvékonyodása; csontdestrukció nincs (piros nyíl)

\section{Mülét}

2018. 12. 13-án autológ hasi zsír augmentációját végeztük.

A mütétet hasi zsírszövet gyüjtésével kezdtük. Alapos jodoformos lemosás után, 0,1\%-os Lidocain-Tonogen infiltrációját követően, a köldök alatt kb. $6 \mathrm{~cm}$-es bőr- 
metszést ejtettünk, disszektorral a hasi zsírszövetig preparáltunk. A megfelelő mennyiségú zsírszövet kinyerése után a sebet két rétegben zártuk, a sebüregben szívódrént hagytunk.

Ezt követően alapos jodoformos lemosás után, 0,1\%-os Lidocain-Tonogen infiltrációját követően, az érintett arc bőrét praeauricularis metszésből indítva az állcsont széle mentén felpreparálva rekeszeket képeztünk a bőr alatt, melybe a korábban eltávolított hasi zsírt augmentáltuk. A sebet két rétegben egyesítettük; mindhárom rekeszbe gumidrént helyeztünk, ezt követően fedőkötés felhelyezése történt.

A teljes mútéti videó a következő linken tekinthetô meg:

https://www.youtube.com/watch? $\mathrm{v}=$ SITeDlotWgo\&t=4s

A posztoperatív ápolás során profilaktikus intravénás antibiotikumos terápia került alkalmazásra, amoxicillinklavulánsav $3 \times 1,2 \mathrm{~g}$, illetve a kialakult ödéma miatt leépítő szteroidos gyulladáscsökkentő kezelést kapott a beteg, metilprednizolont a posztoperatív első napon $2 \times$ $125 \mathrm{mg}$, a második napon $2 \times 80 \mathrm{mg}$, a harmadik napon $2 \times 40 \mathrm{mg}$, a negyedik napon $1 \times 40 \mathrm{mg}$ dózisban.

A korai posztoperatív eredmény szembetúnő volt, sikerült elérni a két arcfél szimmetrikus jellegét (5. ábra).

A beteget mindennapos kötéscserét követően a posztoperatív 8. ápolási napon jó általános állapotban otthonába bocsátottuk. Otthonában amoxicillin-klavulánsav tabletta, 875/125 mg, került felírásra.

A késői posztoperatív szakban, 1 hónappal a mütétet követően, a betegnél a beültetett zsírszövet kismértékú atrofizációja jelentkezett. A betegség inaktív jellege miatt immunológiai követést nem tartottunk szükségesnek.

A beteg a 3 hónapos kontrollvizsgálaton nem jelent meg.

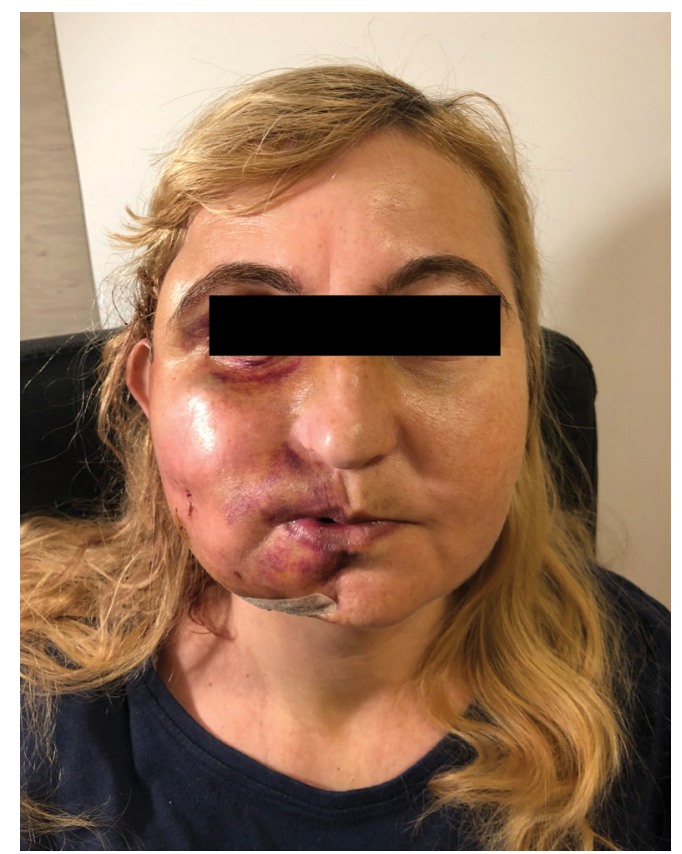

5. ábra

| Posztoperatív kép

\section{Megbeszélés}

A Parry-Romberg-szindróma, vagy más néven progreszszív facialis hemiatrophia, ritka degeneratív betegség, melyet unilateralis arcatrophia jellemez. A betegség autolimitált, egy bizonyos idő után kezelés nélkül is megáll a folyamat progressziója. A leggyakrabban a bőr, a subcutan zsírszövet, ritkábban az izom-, a porc- és a csontszövet lassú és progresszív destrukciója alakul ki, mely az érintett arcfél esztétikáját, illetve funkcionalitását rontja. A betegséget először Parry írta le 1825-ben, majd Romberg 1846-ban pontosította $[1,2]$. Prevalenciája 1/700 000, a nók körében gyakoribb [3].

A PRS kialakulásának pontos patomechanizmusa máig nem tisztázott. Több hipotézis született a kiváltó tényezőt illetően. Az egyik elmélet szerint a PRS autoimmun betegség: az autoreaktív immunsejt vagy az általa termelt autoantitest lerakódik a bör, subcutan zsír-, izom-, porcés csontszövetben, ahol szövetkárosodást okozó, immunmediált gyulladást vált ki, ennek következtében e szövetek lassú és progresszív destrukcióját okozva.

Egyes esetekben a betegség kialakulását mechanikai sérülésből eredeztetik, de a PRS-betegek többségénél nincs traumás kórelőzmény [4]. Bizonyos szerzők a betegség hátterében genetikai okot, szomatikus mutációt feltételeznek. A PRS-betegeknek egyedi proinflammatoricus génexpressziós profiljuk van, ezeknél a betegeknél az IL24, IL8, PROK2, CSF3, C19orf59, ADAMTS4, RTL1, CALCA, DPPA2, HAMP gének fokozott, illetve a WISP2, LOC440925, SCARA5, LCE5A, ZAN, HAND2, OLIG3, C10orf96, TRIM48, OPN1MW2 gének csökkent expresszióját mutatták ki [5]. Az utóbbi időben több publikáció jelent meg, melyekben a borreliosissal hozzák összefüggésbe a megbetegedést, ám nagyobb esetszámot feldolgozó tanulmány még nem készült. A PRS autolimitált jellege miatt a szeropozitív betegeknél alkalmazott antibiotikumkezelés után a betegségben beállt inaktív fázis nem igazolható a terápia hatására [6-8].

A betegségben szenvedő egyén a születéskor teljesen egészséges. A betegség alattomosan alakul ki, az első tünetek általában az egyén első két évtizedében jelennek meg. A betegség tünetei, lefolyása, valamint súlyossága egyénenként jelentős eltérést mutat. A pontos diagnózis felállítása a tünetek megjelenéséhez képest a szakirodalom szerint 9-10 évet késhet.

Gyakran társulnak hozzá neurológiai tünetek: trigeminusneuralgia, paresztézia, migrén, fokális izomrángás, epilepszia. A nervus trigeminus ágai által ellátott terület érintettsége alapján a PRS három formáját különböztetjük meg: enyhe forma esetén a nervus trigeminus egy ága által ellátott terület, középsúlyos forma esetén két ág által ellátott terület csontdestrukció nélkül, súlyos forma esetén mindhárom ág által ellátott területre kiterjedő folyamat, melyhez csontdestrukció is társul [9-11].

$\mathrm{Az}$ érintett területen a bőr száraz, alopeciás, hiperpigmentált folt vagy vitiligo látható [12]. 
A betegség érintheti a szemet, az intraorbitalis zsírszövet elvesztése miatt enophthalmus jöhet létre, jelentkezhet uveitis, látászavar [13]. A betegség érintheti a nyelv azonos oldalát [14].

Előfordulhat, hogy a PRS más lokalizált sclerodermatípusokkal társul: ez lehet morphea vagy lineáris scleroderma. A leggyakrabban az 'en coup de sabre' formával való előfordulást említik, a frontoparietalis régióban paramedián lefutásban a szemöldök és a homlok-hajas fejbőr közötti területen. Egyes szerzők szerint a PRS a lokalizált scleroderma egyik fajtája [15-17].

Differenciáldiagnosztikusan a következő betegségek jönnek szóba: hemifacialis microsomia (Goldenharszindróma) - ez a betegség congenitalis, és nincs progresszió; parciális lipodystrophia (Barraquer-Simonsszindróma), mely általában bilateralis, és először subcutan zsírszövet érintett; trauma, égés, Bell-paresis, egyéb arcidegbénulás, silent sinus szindróma.

A PRS diagnózisát tehát a klinikai kép, a kórlefolyás, az egyéb lehetőségek kizárása, valamint imagisztikai, illetve szövettani vizsgálat alapján lehet felállítani [18].

A PRS lefolyásában két szakaszt különítünk el: aktív, vagy progresszív fázis, ez általában húsz évet foglal magában, amelyet az inaktív fázis követ, ilyenkor a folyamat irreverzibilis.

A PRS kezelése komplex, multidiszciplináris, és nincs egységes kezelési séma.

Az aktív szakaszban: lokális kezelésként közepesen erős szteroidkészítmények, szisztémás kezelésként immunszuppresszív terápia (metotrexáte, kortikoszteroidok, cychlophosphamide, azathioprine), illetve antimaláriás szerek (hydroxichloroquine, chloroquine) kerültek alkalmazásra [19-21].

Rekonstrukciós mütétek akkor jönnek szóba, ha a betegség progressziója leállt.

Az inaktív szakaszban a kialakult deformitás típusától függően választjuk meg a rekonstrukciós lehetőségeket.

I. típus: kismértékü eltérés észlelhető a két oldal között, mely a bőrre korlátozódik.

II. típus: a két oldal közötti differencia szembetúnő, érintett a subcutis, nem érinti az izmot, illetve a csontot.

III. típus: érinti az izmot, csontot.

IV. típus: súlyos deformitás, funkcionális problémákat okoz.

Az I., illetve a II. típusban különböző módszerekkel történő autológzsír-beültetés jön szóba. A III., illetve a IV. típusnál kombinált beavatkozás szükséges: lebenypótlás, porc-, illetve csontgraftok beültetése, autológzsír-beültetés [22, 23].

A lebenypótlás történhet nyeles lebennyel vagy microvascularis szabad bőrlebennyel [24].

Az autológ zsír nyerhető leszívásos módszerrel, illetve sebészi kimetszéssel. A beavatkozás előnye, hogy költséghatékony, a betegnek kis megterhelést jelent. A poszt- operatív szakban a következő szövődmények léphetnek fel: a graft elmozdulása, ödéma, ecchymosis, liponecrosis, seroma, atrophia.

Sebészi kimetszéses módszer esetén a beültetés alagútképzéses technikával történik, mely a graftnak kellő stabilitást ad. A posztoperatív szakban fellépő zsírszövetatrophia miatt gyakran előfordul, hogy több beavatkozás szükséges a kellő esztétikai eredmény hosszú távú elérése érdekében [25-27].

A cseplesz mikrosebészeti átültetésével kis esetszámú publikációkban kedvező eredmények születtek. A cseplesz mint autológ graft előnye, hogy nagy defektus rekonstrukciójához is kellő mennyiség nyerhető belőle, bármilyen alakra formálható, és kellően tág erekkel rendelkezik az éranasztomózisok kivitelezéséhez. Hátránya, hogy a lebeny kinyeréséhez laparoszkópos mútét szükséges, illetve a környező fasciához, periosteumhoz nem megfelelően rögzített cseplesz könnyen elcsúszhat [28].

A betegség aktív szakaszában történő sikeres rekonstrukcióra kis esetszámú szakirodalmi adat áll rendelkezésre, ezeknél az eseteknél őssejtekkel dúsított sajátzsír-beültetés történt $[29,30]$.

\section{Következtetés}

A gyermekkorban induló tünetek, a lassú progresszió, a fizikai status, a képalkotó vizsgálatok, a labor-, immunszerológiai vizsgálatok, a szövettan alapján a bemutatott betegnél egy ritka betegség, a PRS, és emellett a beteg hátán a lokalizált scleroderma morpheának megfelelő eltérés igazolódott. A betegség diagnózisát késleltette a lassú progresszió, a betegség multidiszciplináris jellege, a kórkép ritkasága, illetve a kórelőzményben előforduló baleset (mész cseppent a szemébe).

A diagnózis késése miatt a betegség progressziójával ezen betegnél visszafordíthatatlan deformitások alakultak ki. A mútéti megoldás gyakran multidiszciplináris (fül-orr-gégész, plasztikai sebész, szájsebész), többüléses. Amennyiben a betegség még aktív fázisban van, a mütéti megoldás értelmetlen.

Az elvégzett vizsgálatok alapján felmerül a borreliosis szerepe mint a betegség kiváltó oka.

Anyagi támogatás: A kézirat elkészítése anyagi támogatásban nem részesült.

Szerzôi munkamegosztás: T. T.: Az információk begyưjtése, feldolgozása, a kézirat megírása, mütéti asszisztencia. I. Z.: Az információk begyưjéése. Sz. G.: Immunszerológiai vizsgálatok végzése. K. T.: Iránymutatás, a diagnózis felállítása, a mütétek elvégzése. A cikk végleges változatát valamennyi szerző elolvasta és jóváhagyta.

Érdekeltségek: A szerzőknek nincsenek érdekeltségeik. 


\section{Irodalom}

[1] Sharma M, Bharatha A, Antonyshyn OM, et al. Case 178: ParryRomberg syndrome. Radiology 2012; 262: 721-725.

[2] Rangare AL, Babu SG, Thomas PS, et al. Parry-Romberg syndrome: a rare case report. J Oral Maxillofac Res. 2011; 2: e5.

[3] Gupta S, Mathur M. "The unkindest cut of all”: Parry-Romberg syndrome - an unwonted affair. J Clin Diagn Res. 2016; 10: TJ01-TJ02.

[4] Wong M, Phillips CD, Hagiwara M, et al. Parry-Romberg syndrome: 7 cases and literature review. Am J Neuroradiol. 2015; 36: 1355-1361.

[5] Chen JT, Eisinger B, Esguibel C, et al. Changes in cutaneous gene expression after microvascular free tissue transfer in ParryRomberg syndrome. Plast Reconstr Surg. 2018; 142: 303e$309 \mathrm{e}$.

[6] di Meo N, Stinco G, Nan K, et al. Parry-Romberg syndrome: a case with a possible association with Lyme disease. Acta Dermatovenorol Alp Pannonica Adriat. 2015; 24: 77-79.

[7] Sahin MT, Bariş S, Karaman A. Parry-Romberg syndrome: a possible association with borreliosis. J Eur Acad Dermatol Venereol. 2004; 18: 204-207.

[8] Gutiérrez-Gómez C, Godínez-Hana AL, García-Hernández M, et al. Lack of IgG antibody seropositivity to Borrelia burgdorferi in patients with Parry-Romberg syndrome and linear morphea en coup de sabre in Mexico. Int J Dermatol. 2014; 53: 947-951.

[9] Latha S, Shefali J, Jaideep S, et al. Parry-Romberg syndrome: a case report and review. Int J Appl Dent Sci. 2016; 2: 75-78.

[10] Haldar A, Mukherjee A. Parry-Romberg's disease with intractable partial epilepsy. Neurol India 2007; 55: 160-162.

[11] Gulati S, Jain V, Garg G. Parry-Romberg syndrome. Indian J Pediatr. 2006; 73: 448-449.

[12] Madasamy R, Jayanandan M, Adhavan UR, et al. Parry-Romberg syndrome: a case report and discussion. J Oral Maxillofac Pathol. 2012; 16: 406-410.

[13] Bucher F, Fricke J, Neugebauer A, et al. Ophthalmological manifestations of Parry-Romberg syndrome. Surv Ophthalmol. 2016; 61: 693-701

[14] Chhabra A, Lam JM, Rhemus W. Tongue involvement in ParryRomberg syndrome. J Rheumatol. 2017; 44: 1412.

[15] Khan M, Khan M, Negi R, et al. Parry-Romberg syndrome with localized scleroderma: a case report. J Clin Exp Dent. 2014; 6: e313-e316.

[16] Kiss VP, Pere T, Karagity E, et al. Localised scleroderma on face (en coup de sabre) - case report. [Lokalizált scleroderma arcon (en coup de sabre) - betegbemutatás.] Bőrgyógy Venerol Szle. 2017; 93: 39-41. [Hungarian]

[17] Stone J. Parry-Romberg syndrome. Pract Neurol. 2006; 6: 185188 .
[18] Patel H, Thakkar C, Patel K. Parry-Romberg syndrome: a rare entity. J Maxillofac Oral Surg. 2010; 9: 247-250.

[19] Tollefson MM, Witman PM. En coup de sabre morphea and Parry-Romberg syndrome: a retrospective review of 54 patients. J Am Acad Dermatol. 2007; 56: 257-263.

[20] Sommer A, Gambichler T, Bacharach-Buhles M, et al. Clinical and serological characteristics of progressive facial hemiatrophy: a case series of 12 patients. J Am Acad Dermatol. 2006; 54: 227233.

[21] Korkmaz C, Adapinar B, Uysal S. Beneficial effect of immunosuppressive drugs on Parry-Romberg syndrome: a case report and review of the literature. South Med J. 2005; 98: 940-942.

[22] Guerrerosantos J, Guerrerosantos F, Orozco J. Classification and treatment of facial tissue atrophy in Parry-Romberg disease. Aesthetic Plast Surg. 2007; 31: 424-434.

[23] Agostini T, Spinelli G, Marino G, et al. Esthetic restoration in progressive hemifacial atrophy (Romberg disease): structural fat grafting versus local/free flaps. J Craniofac Surg. 2014; 25: 783787.

[24] Chen JT, Schmid DB, Siebert JW. A 26-year experience with microsurgical reconstruction of hemifacial atrophy and linear scleroderma. Plast Reconstr Surg. 2018; 142: 1275-1283.

[25] Simonacci F, Bertozzi N, Grieco MP, et al. Procedure, applications, and outcomes of autologous fat grafting. Ann Med Surg. 2017; 20: 49-60.

[26] Balaji SM. Subdermal fat grafting for Parry-Romberg syndrome. Ann Maxillofac Surg. 2014; 4: 55-59.

[27] Sterodimas A, Huanquipaco JC, Filho SS, Autologous fat transplantation for the treatment of Parry-Romberg syndrome. J Plast Reconstr Aesthet Surg. 2009; 62: e424-e426.

[28] Asai S, Kamei Y, Nishibori K, et al. Reconstruction of Romberg disease defects by omental flap. Ann Plast Surg. 2006; 57: 154158.

[29] Hunstad JP, Shifrin DA, Kortesis BG. Successful treatment of Parry-Romberg syndrome with autologous fat grafting: 14-year follow-up and review. Ann Plast Surg. 2011; 67: 423-425.

[30] Koh KS, Oh TS, Kim H, et al. Clinical application of human adipose tissue-derived mesenchymal stem cells in progressive hemifacial atrophy (Parry-Romberg disease) with microfat grafting techniques using 3-dimensional computed tomography and 3-dimensional camera. Ann Plast Surg. 2012; 69: 331-337.

(Tamás Tímea dr., Miskolc, Szentpéteri kapu 72-76., 3526 e-mail: tamiiil6@yahoo.com)

A cikk a Creative Commons Attribution 4.0 International License (https://creativecommons.org/licenses/by/4.0/) feltételei szerint publikált Open Access közlemény, melynek szellemében a cikk bármilyen médiumban szabadon felhasználható, megosztható és újraközölhető, feltéve, hogy az eredeti szerző és a közlés helye, illetve a CC License linkje és az esetlegesen végrehajtott módositások feltüntetésre kerülnek. (SID_1) 